\title{
Locus of control and technostress in Nigeria commercial banks: The nexus
}

Dibua Emmanuel Chijioke ${ }^{1 *}$, Chitom Racheal John-Akamelu², Nwanmuoh Emmanuel Ejiofor ${ }^{3}$ Department of Business Administration, Faculty of Management Science, Nnamdi Azikiwe University, Awka, Nigeria ${ }^{1}$

Department of Accountancy, Faculty of Management Science, Nnamdi Azikiwe University, Awka, Nigeria $^{2}$

Department of Marketing, Faculty of Business Administration, University of Nigeria, Nsuka, Nigeria ${ }^{3}$ ec.dibua@unizik.edu.ng ${ }^{1}$,cr.johnakamelu@unizik.edu.ng ${ }^{2}$,emmauel.nwanmuoh@unn.edu.ng ${ }^{3}$

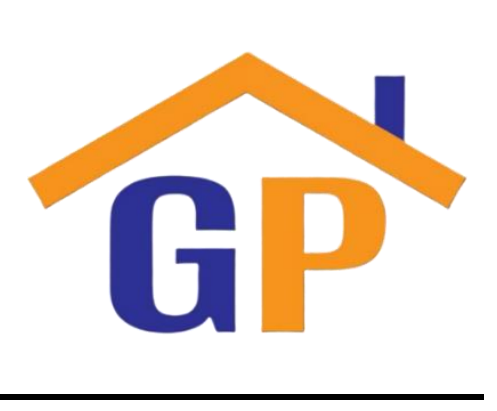

Article History

Received on 5 March 2021

$1^{\text {st }}$ Revision on 12 March 2021

$2^{\text {nd }}$ Revision on 1 April 2021

$3^{\text {rd }}$ Revision on 21 April 2021

Accepted on 21 April 2021

\begin{abstract}
Purpose: This study aimed to ascertain the connection between LOC and Technostress in selected commercial banks in Nigeria.
\end{abstract}

Research methodology: Survey research design was employed in this study. The study population was 400 while the sample size was 191 employees of the selected banks, arrived at through the usage of Taro Yamane formula. The instrument for data collection was a Likert Structured Questionnaire that was put through validity and reliability test. The data were analyzed with Pearson's correlation analysis, while the hypothesis was tested at 0.05 level of significance.

Result: There is a significant nexus between external LOC and techno-invasion in the Banks selected $(r=.942$, $\mathrm{p}$-value $<0.05)$. The increase in technological deployment and the seeming lack of control by employees lead to techno-invasion and, by extension, technostress.

Limitations: The generalizability of the study was limited by not collecting data from a cross-section of respondents from the entire country.

Contribution: This is a novel study in the area of LOC and technostress in Nigeria.

Keywords: Locus of control, Stress, Technostress, External locus of control, Techno-invasion

How to cite: Chijioke, D. E., John-Akamelu, C. R., \& Ejiofor, N. E. (2021). Locus of control and technostress in Nigeria commercial banks: The nexus. International Journal of Financial, Accounting, and Management, 3(1), 83-92.

\section{Introduction}

Every formed organization was created to fulfil a purpose. The purpose could be to produce a product or service or to combine both, all in a bid to satisfy an aim or objective. However, most central in the achievement of this goal is employees, as they have been regarded by many researchers as the most important asset at the disposal of most organizations, if harnessed and managed properly. This was the submission of Soleh, Noviantoro and Putrafinaldo (2020) who aver that Human Resources (HR) is an important resource for any organization, hence, for optimal organizational performance, they need to be managed appropriately. Human capital is an asset that is most central to the competitiveness and survival of an organization (Hauff, Richter \&Tressin, 2015; Kobersy,Khasiyeva, Yakhina, Ignaryeva, Goloshchapova\&Shkurkin, 2016).

Employees as people differ in many ways, their age, educational level, temperament, gender, emotional level, intellectual quotient and background. Some differ in the colour of skin, height and personality. All these differences make them react differently to similar situations at the same or 
different times. The most important construct in determining the reactions and views of employees about what is happening to them is their personality. There are various forms of personalities, but the most pertinent in organizations is called locus of control (LOC). LOC is one of many personality variables that have been researched in various organizational settings(Suherlan, Wahyuni \& Hazairin, 2017). It is a construct that gives meaning to what happens to employees and the level of control they perceive to have over it. One's LOC defines their beliefs about what is happening in the world around them and the events that are comprised init and those that control it (Houston, 2011; Nguyen, 2013).

The view of an employee about what happens to them in an organization and the amount of control they can exert over it defines their LOC. Omukhango (2016) avers that LOC is a psychological concept related to a person's belief in what is responsible for outcomes and results in personal or organizational life. It influences a person's response to the events perceived and the motivation to take action and our beliefs about what causes our actions and then influences our behavior and attitudes (Boondhalir \& Sajeethkumar, 2020).

Some people believe that what happens to them is within their control. In contrast, others see what happens to them as being completely out of their control, thereby bringing to the fore the dimensions of LOC, which is usually two, the external LOC and internal LOC. Cetin (2008) opines that individuals lay out two control attitudes as internal and external, depending on their control power over outcomes of life. Those that are confident in their ability to influence outcomes in their lives are regarded as having internal LOC while those that believe that what happens to them is out of their control posses external LOC. Internals have a tendency to credit themselves for the outcomes of events to their lives whileexternals tend to credit external circumstances and influences for the outcomes of their actions and inactions in life(Boondhalir \& Sajeethkumar, 2020).

However, the crux of this study is to examine how external LOC correlates with techno-invasion, as LOC has been observed to influence related organizational variables. Asiedu-Appiah and Addai (2014) explicate that LOC is associated with numerous salient work outcomes such as job satisfaction, employee commitment and engagement, job performance and stress levels. Similarly, Dayo (2012) that LOC has been found to have a far-reaching impact on organizations. Stress level is attributed to many things and could be influenced by LOC in organizations. Stress emanates from different facets of organizational engagement, but the interest in this study emanates from the excessive or wrong deployment of technology, regarded as "Technostress".

Banks around the world and in Nigeria are known for their extensive application of Information and Communication Technology (ICT) in the discharge of their duties, to keep up with customers' dynamic needs. This has led to the usage of different kinds of technology, some get obsolete very fast and a new one introduced with great pace. Sometimes, the employees seem overwhelmed by these technologies that they become stressed up. So, the inability to appropriately use, adopt and deploy ICT leads to what is called technostress. These employees sometimes appear helpless; they cannot help but flow with the innovations in terms of technological deployments in their organizations, making them appear to have external LOC as regards technology and its adaptation or adoptions. Hence, this study necessitates examining how LOC correlates with technostress in commercial Banks in Nigeria as a broad objective. Specifically, the study examines the nexus between external LOC and techno-invasion in selected commercial banks in Nigeria.

\section{Review of related literature}

\subsection{Conceptual review}

\subsubsection{Locus of control}

The way individuals perceive what happens to them as either being under their control or beyond them defines their LOC. LOC is a term that tries to measure and assign meaning to what happens to people as being under their control or at the mercy of extraneous factors like luck, fate or happenstance. Robbins (2003) avers that LOC is a person's perception of his fate source. Robbins and Judge (2014) see it as the degree to which individuals believe that they are determinants of their destiny. It encompasses the belief individuals have throughout their lives and their analysis of their 
actions and inaction and what is attributed for such outcomes, whether it comes or happens because of chance, fate or outside forces (Erdogan, 2003).

Locus of control is the belief of an individual about what is responsible for the good or bad outcomes. It results in different facets of their life, such as in an organizational setting, health standing and status, academics and or spiritual engagements (Vijayashreea \& Jagdischchandra, 2011). Some believe that what happens in their lives is up to them to control and dictate, while others see themselves as helpless in determining the outcomes in their lives. LOCis a personality attribute showing the widespread belief that events in life are either influenced by the action that one takes or by extraneous factors beyond the very control of such an individual (Hurrell, Levi \& Murphy, 2011). Nasrullah, Armanu and Setiawan (2013) point out that some individuals are of the view that they can influence their life's outcome, while another group of individuals view what happens to them as being attributed to outside influences like fate, luck and happenstance. These two varying views bring to the fore the two dimensions of LOC: either internal LOC or external LOC. Internal is the attitude of the individual who has a belief that he is the holder of whatever happens to himself, while external is someone who has the belief that what happens to them is controlled by external forces (Soleh, Noviantoro \& Putrafinaldo, 2020).

Those with internal LOC think that they can influence their fate and that their behaviors have a role to play in affecting the outcomes of events in their lives(Olonade, Ajibola, Oyewumi, Olusesi \& Bamidele, 2020). While those with external LOC see what happens to them as beyond their immediate control, they cannot do anything about it but resign themselves to fate. The main focus of this study is on external LOC and how it influences techno-invasion as a construct used in measuring technostress.

\subsubsection{External LOC}

There are two dimensions of LOC; one is internal while the other is the external LOC. The concern of this study is external. Those with external LOC believe in their lack of control or ability over what happens to them. They leave everything to chance, fate, luck or other extraneous variables. Those with an external locus of control believe that fate, luck or extraneous variables play a significant role in determining their success (Olonade et al., 2020). Hurrell et al. (2011) opine that individuals with external LOCthink that they have minimal control over the events of life and circumstances and attribute reinforcements to powerful others or luck. They believe that the outcome of an event is largely outside their control (external factors) (Yuwono, Eliyana, Buchdadi, Hamidah, Sariwulan, Handicapilano, 2020). People with this control dimension believe in luck and people power (Khushk, 2019).

The control level ascribed by people with external LOC makes them agree that other people and the general system have great control over their life outcomes. Hale (2012) posits that the environment and other people within their domain influence those with external LOC are against them influencing and affecting others as it is in the case of internal LOC individuals. Their thinking always is that fate, luck, chance and opportunities are the major drivers of success in their lives, and are, therefore, always feeling overwhelmed by external factors and other people whenever they view the outcomes of their lives as epic failures (Gangai, Mahakud \& Sharma, 2016). The power to directly control their destiny and fate is out of the hands of those with external LOC. Therefore, they feel they are playing a reactive role with regard to the environment and outcomes therein (Thomas, Kelly \& Lillian, 2006). People associated with an external locus of control perceive the environmental and situational factors as playing preeminent roles in their lives rather than the credence they give to internal factors(Babalola, 2009 cited in Dayo, 2012).

People that have an external posture to control tend to believe that they are at the mercy of others. Therefore, they always play the victim, are laid back and always want to be told what to do. Manichander (2014) states that persons with an external LOCwill most likely see themselves as "Victims". They feel they are helpless and powerless, and therefore, likely to indulge in "victim mentality" or behavior. The effort to carry out their daily activities is usually not enough and they tend to get frustrated easily and are easily distracted and give up rapidly. This action may make such 
people unwilling to seek creative ways to better the situation. They may even stay in a job where dissatisfaction is visible, rather than taking actions that will change the situation or change the extant environment (Gangai et al., 2016; Hale, 2012; Sharma \& Sharma, 2015). Also associated with such kind of people are attributes of being easygoing and laid back; they prefer to be given directions, to be ordered around and told what to do as opposed to taking charge and actively seeking knowledge and information that will stand them out (Gangai et al., 2016).

\subsubsection{Technostress}

Information and Communication Technology (ICT) has been observed to help make our lives a lot easier and stress-free. People can now do a lot more work, with a lot less stress and in record time. However, just like it is with almost everything in life, there are some bad sides. When people are inundated by the dynamism of technology and find it difficult to cope with its demand, it results to stress, termed technostress.

Stress generally is the inability to cope with certain situations in life, thereby affecting people's mood, dispositions and reactions to things. Boondhalir and Sajeethkumar (2020) state that stress is a situation where the well-being of individuals is detrimentally affected by their failure to cope with the demands of their environment and it is one of the highest health risks is influencing employees, regardless of the size of the organization. It is any adjective demand on an individual caused by physical, emotional or mental factors that demand coping behavior (Alam, Gouhar \& Shafiqur, 2015). Sun and Chiou (2011) describe it as being associated with a negative emotional experience accompanied by biochemical, physiological, cognitive and behavioral changes that are predictable and are channeled either toward changing the events or working assiduously to accommodate its consequences. Difficulties encountered by someone while trying to adjust to an environment result in stress, hence the inability to adapt to the demands of technology as technostress.

Technostress is a form of stress that results from the inability of workers to adjust to the demand of technology in their organizations appropriately. Tiemo and Ofua (2010) aver that it is associated with the inability to cope with modern technologies in a way that could be termed healthy and responsive. With new technology comes new demand in the form of adoption, training, unlearning and demand more efficiently. The accumulation of these situations and the inability to meet these demands results in technostress. Agbu and Olubiyi (2011) aver that the speedy introduction of information and communication technology in the place of work may lead to employees suffering from a combination of technology fatigue, stress and discomfort, which is regarded as technostress. That is circumstances in which a person cannot cope and accept the technological changes, adoption and adaption in the workplace (Ennis, 2005).

\subsubsection{Techno-invasion}

Technology has been one of the finest innovations of humans over the last century. This is because it helps to lessen the burdens of carrying out some duties, reduces time spent doing some kinds of jobs and shrinks time and space. With the advent of technology, people can work together remotely from around the world in real-time. However, this does come with some side effects as it has been accused of being responsible for evading people's privacy, technically called techno-invasion. Literature is bound with evidence of technology helping organizations to increase employee productivity, work flexibility (Stough, Eom \& Buckenmyer, 2000) and performance (Mohanta, Kannan, \& Thooyamani, 2006); there is also evidence of technology potentially infringing on the private life of people, invading privacy and causing techno-stress (Mazmanian, Orlikowski, \& Yates, 2006).

When people can no longer be confident about when they are actually free from work and when they are not, it is an issue of private life invasion. Invasion of privacy has to do with the belief that a person's privacy has been compromised (Alge, 2001). More so, when this compromise or infringement of peoples private life is giving a fillip to, by technology, it is termed techno-invasion. Therefore, techno-invasion is a technology-aided invasion of privacy; infringement of people's private life orchestrated by others through technology. Techno-invasion identifies technology as a source of blurring boundaries between the work and private domains (Maier, 2014). 
The invasion of employees' private life through technology is not helped because some organizations provide these technological gadgets for the employees and provide subscriptions for them, thereby expecting them to be reachable all they and ready to respond to organizational demands. Since many establishments cater to their workers' cell phone bills, they expect the employees to pick up calls at any point in time; even in their personal and private time (Soylu\& Campbell, 2012; Taylor, Fieldman \& Altman, 2008). As a result of this, work time has invaded into private and personal time, thereby leading to stress in most situations. Mandel (2005) avers that one of the related consequences of this is employees' workdays get extended, often by as much as two to three hours daily. These extra hours are being spent using communication devices such as email applications and smartphones, many times during odd hours, hitherto private hours. Mahboob and Khan (2016) posit that the use of technology in the workplace through various devices interferes with people's personal time dimension and may lead to stressful work experiences. These interferences with the personal life of employees as a result of technology may completely be beyond the control of employees. Hence, it could be said that employees have external LOC when it comes to technology usage in the workplace.

\subsection{Empirical review}

Yuwono, Eliyana, Buchdadi, Hamidah, Sariwulan and Handicapilano (2020) studied the effect of locus of control on employee job satisfaction. The study population was made up of employees of GraPARI Telkomsel Surabaya, with a sample size of 43 employees. The data analysis method deployed by the study was Partial Least Square, through the use of path analysis. Emanating from the result, it was revealed that internal locus of control has a significant positive and influence on employees' job satisfaction in the studied organization.

Boondhalir and Sajeethkumar (2020) did a study to identify the relationship between work locus of control and occupational stress. The tools used in the study are the work locus of control scale by

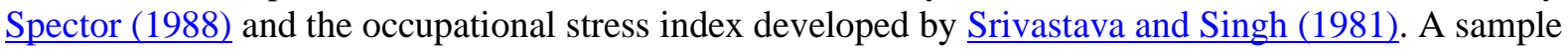
of 100 people was selected for the study selected using a stratified random sampling technique. The results showed that the employees differ in work locus of control and occupational stress based on age and do not differ based on gender. The correlation analysis result indicated that there is a statistically significant positive relationship between work locus of control and occupational stress.

Khushk (2019) carried out a study in Pakistan to examine the impact of internal and external locus of control (LOC) and organizational commitment on employee performance. The work was a survey study. It collected data using a closed-ended questionnaire were designed using a Likert scale format. Pearson's correlation was used for data analysis. Findings from the analysis indicated that a medium correlation exists between locus of control and employee performance and that it does not reveal enough evidence of being significant. However, a strong nexus with evidence of significance was seen between employee organizational commitment and employee performance. This shows that employees who possess an internal locus of control think employee performance is hinged on the commitment level of employees, whereas, for those whose locus of control is external, they believe that organizational commitment is not necessarily significant in playing a role in employee performance.

Kalyanasundaram, Manickam and Senthilkumar (2018) assessed whether the internal or external locus of control relates to the organization stress of employees in India. The study employed both descriptive and inferential statistical analysis. The findings showed that employees are battling major stress situations in India. Also arising from the analysis is that employees whose locus of control is regarded as internal to them do not experience much stress from the execution of their jobs and playing their assigned roles and derive a lot more satisfaction in the organization. On the other hand, a high-stress situation and monumental dissatisfaction are associated with employees whose locus of control is external.

Qadri, Hassan and Sheikh (2017) investigated the mediating effect of internal locus of control (ILOC) and job stress (JS) between spiritual intelligence (SI) and job performance (JP) in Pakistan. The data used for the study was ascertained employees in several managerial positions in many textile 
companies in the province of Punjab from, they were 425 in number. The data so collected was analyzed with the use of Structural Equation Modeling(SEM). The findings revealed that internal locus of control and job stress partially mediate the correlation between the employees' spiritual intelligence and job performance.

Syahputra (2014) carried out a study in Indonesia to determine the organizational culture in the workplace as a moderation variable of the effect of organizational commitment and locus of control on employee's job satisfaction and implication on job performance. The data utilized by the study were collected through the distribution of and collection of a questionnaire. The hypothesis formulated for the study was tested using Structure Equation Modeling (SEM). The results emanating from the analysis showed that good commitment to the job and the organization could increase job satisfaction. However, no significant effect was found on job satisfaction by locus of control, whereas high job satisfaction significantly improved employee performance.

Chuang and Chien(2013) examined the relationship between external LOCand Coping Behavior among Agency Workers of retail stores in Taiwan. The instrument for data collection was a questionnaire distributed to 250 employees, and at the end 230, were returned, but a total of 212 valid questionnaires were finally used (analyzed). The analysis findings revealed a strong and significant nexus between agency workers, external LOC, and job satisfaction in the firms studied. Also, coping behavior significantly influenced job satisfaction, and external LOCwas seen to affect job satisfaction significantly.

In Nigeria, Akintayo (2012) carried out a study to ascertain the influence of locus of control and job satisfaction on perceived non-teaching staffs' productivity in higher institutions in Ogun State. The study adopted a descriptive survey design with a total population of 341 respondents. These respondents were selected using a proportionate stratified sampling technique. A structured questionnaire titled "Locus of Control Scale (LCS), Job Satisfaction Scale (JSS) and Workers' Productivity Scales (PWPS)were deployed to aid in data collection. The hypotheses were tested using Regression Analysis and Pearson Product Moment Correlation Statistics. The findings from the analyses revealed that locus of control and job satisfaction have jointly contributed to perceived nonteaching staff productivity in selected higher institutions in Ogun State. Similarly, job satisfaction was found to have significantly influenced perceived non-teaching staffs' productivity in the state of interest.

\subsection{The hypothesis of the study}

There is a significant nexus between external LOC and techno-invasion in selected commercial banks in Nigeria.

\section{Research methodology}

A survey research design was deployed for the study, with a population of 400 commercial bank workers of all categories selected from the five states comprising southeast of Nigeria. The sample size determined using Taro Yamane was 191 and randomly selected using a simple random sampling technique. The instrument for data collection was a 5 point Likert scale structured questionnaire and was allocated appropriately using Bowley's allocation formula. The instrument was put through a validity test by subjecting it to face and content validity, while its consistency was ascertained using the Split-Half technique, which returned a coefficient of 0.884 . The data collected was analyzed using Pearson's Product Moment Correlation Coefficient (PPMCC) and the hypothesis was tested at a 5\% level of significance. The copies of the questionnaire used for the analysis were 175 because out of the 190 distributed copies, only 179 were returned, 4 out of the returned copies were not usable as some were incompletely filled while others were mutilated beyond usage. 


\section{Results and discussions}

\subsection{Data presentation and analysis}

Table 1. Responses from respondents on external LOC and techno-invasion

\begin{tabular}{|c|c|c|c|c|c|c|c|}
\hline $\mathbf{S} / \mathbf{N}$ & Questionnaire Items & $\begin{array}{l}\text { SA } \\
(5)\end{array}$ & $\begin{array}{l}\text { A } \\
(4)\end{array}$ & $\begin{array}{l}\text { UD } \\
\text { (3) }\end{array}$ & $\begin{array}{l}\mathbf{D} \\
(2)\end{array}$ & $\begin{array}{l}\text { SD } \\
(1)\end{array}$ & Mean \\
\hline & External LOC & & & & & & \\
\hline 1 & $\begin{array}{l}\text { I do not have control over the kind of technology my } \\
\text { organization deploys. }\end{array}$ & 70 & 83 & - & 22 & - & 4.15 \\
\hline 2 & $\begin{array}{l}\text { My organization does not sort for opinions before asking me to } \\
\text { start using new technologies. }\end{array}$ & 71 & 99 & - & 5 & - & 4.35 \\
\hline 3 & Other people control everything ICT in my workplace. & 70 & 81 & 9 & 10 & 5 & 4.15 \\
\hline \multirow[t]{2}{*}{4} & $\begin{array}{l}\text { The external environment determines the technology we use in } \\
\text { my firm. }\end{array}$ & 48 & 72 & 23 & 20 & 12 & 3.70 \\
\hline & Techno-invasion & & & & & & \\
\hline 5 & I am usually called at odd hours to attend to office duties. & 49 & 67 & - & 39 & 20 & 3.49 \\
\hline 6 & $\begin{array}{l}\text { I no longer have private time as I am always ready to expect } \\
\text { calls and emails to attend to any time of the day. }\end{array}$ & 80 & 72 & - & 6 & 17 & 4.10 \\
\hline 7 & $\begin{array}{l}\text { Technology has extended my work hours as I even work from } \\
\text { home even at night. }\end{array}$ & 101 & 50 & & 24 & - & 4.30 \\
\hline 8 & $\begin{array}{l}\text { I will prefer to have my own private time with no disturbance } \\
\text { from my office. }\end{array}$ & 111 & 64 & - & - & - & 4.63 \\
\hline
\end{tabular}

Source: Field Survey, 2021

Table 1 shows the distribution of respondents' responses for external LOC and techno-invasion in the Banks selected. The analysis was based on a mean, with a threshold of 3 . Any questionnaire item with a mean of 3 is regarded as accepted and true, while those with a mean of below 3 are regarded as rejected and not being true. The Table shows that all the questionnaire items have a mean of above 3, and therefore, are all accepted. Specifically, it goes to show that the respondents agreed that they do not have control over the kind of technology their organizations deploy. Also, they agreed that their organization do not sort for opinions before asking them to start using new technologies. Similarly, they concurred that other people control everything ICT in their workplace. This same line of response was gotten when asked if the external environment determines the technology they use in their firm. These were questionnaire items used in measuring LOC. For questions used to measure techno-invasion, the respondents agreed that they are usually called at odd hours to attend to office duties. They also agreed that they no longer have private time as they are always ready to expect calls and emails to attend to any time of the day. The same goes for when they were asked if technology has extended their work hours as they even work from home even at night and prefer to have their own private time with no disturbance from their offices.

Table 2. Correlation analysis

\begin{tabular}{|c|c|c|c|}
\hline & & ELOC & $\begin{array}{c}\text { TECHIN } \\
\mathrm{V}\end{array}$ \\
\hline \multirow[t]{3}{*}{$\overline{E L O C}$} & $\begin{array}{l}\text { Pearson } \\
\text { Correlation }\end{array}$ & 1 & $.942^{\star \star}$ \\
\hline & Sig. (2-tailed) & & .000 \\
\hline & $\mathrm{N}$ & 175 & 175 \\
\hline \multirow[t]{3}{*}{$\begin{array}{l}\text { TECHIN } \\
\mathrm{V}\end{array}$} & $\begin{array}{l}\text { Pearson } \\
\text { Correlation }\end{array}$ & $.942^{* *}$ & 1 \\
\hline & Sig. (2-tailed) & .000 & \\
\hline & $\mathrm{N}$ & 175 & 175 \\
\hline
\end{tabular}

${ }^{* *}$. Correlation is significant at the 0.01 level (2tailed).

Source: Field Survey, 2021 
Table 2 shows the correlation analysis for external LOC and techno-invasion in the Banks selected. From the result, the correlation coefficient as depicted by $\mathrm{r}$ is .942 . At the same time, the probability value (p-value) as represented by sig is .000 (p-value < 0.05 ). This alternate hypothesis states that a significant nexus between external LOC and techno-invasion in the Banks selected is accepted.

\subsection{Discussions}

The findings from the analysis carried out indicated that there is a statistically significant positive relationship between external LOC and techno-invasion in the Banks selected in Nigeria. This signifies that as the level of control employees have is increasingly associated with external influence, the more stress associated with technology that the employees will have. That is, when workers have no control over what type of technology is being deployed, how and when to use and what to use it for, the more the management of the organizations will use the technologies to inundate the workers with workloads, invade their private lives in a bid to get the best out of them, which will lead to a stressful situation to the employees. This finding corroborates that of Boondhalir and Sajeethkumar (2020) that carried out a study to examine the nexus between work locus of control and occupational stress. From their findings, it was revealed that there is a statistically significant positive relationship between work locus of control and occupational stress. Occupational stress may come in different ways, technostress and its component techno-invasion being among the numerous forms of stress employees could encounter while discharging their duties in their organizations. Similarly, the present study's finding aligns with that of Kalyanasundaram, Manickam and Senthilkumar (2018)that assessed whether the internal or external locus of control relates to organizational stress of employees in India. Part of their findings was that external locus of control employees are highly stressed and more dissatisfied with their jobs.

\section{Conclusion}

Employees are the bedrock of most organizations. Their well-being is therefore paramount. Their performance, to a great extent, determines the sustainability of firms. Banks to stay ahead of competition introduce ICT to help improve service deliveries to customers. However, employees do not have a say in determining when and how to deploy these technologies, as seen from the employees' responses. This affects the level of control they have over the usage of these technologies, leading to stress. This study, therefore, concludes that the increase in technological deployment and the seeming lack of control by employees leads to techno-invasion in the banks selected for the study, and by extension, other banks of the same characteristics.

\section{Recommendations}

The study makes the following recommendations:

a) The management of the studied firms needs to apply caution in deploying different technologies in the firms as this could potentially lead to stressful situations for the employees.

b) As much as possible, the employees' private time need not be invaded by the organization in a quest to meet deadlines and improve performance, as this could be counterproductive.

\section{References}

Agbu, J. O., \& Olubiyi, O. K. (2011). Technostress in the age of information communication technology: A case study of distance education. Educational Research, 2(11), 1654-1660.

Akintayo, D. (2012). Locus of control and job satisfaction as predictors of perceived non-teaching staffs` productivity in higher institutions in Ogun State, Nigeria. Global Advanced Research Journal of Management and Business Studies, 1(6), 181-187.

Alam, Z., Gouhar, S., \& Shafiqur, R. (2015). The impact of job stress on employee's performance: investigating the moderating effect of employees' motivation. City University Research Journal, 5(1), 120 - 129.

Alge, B. J. (2001). Effects of computer surveillance on perceptions of privacy and procedural justice. Journal of Applied Psychology, 84(6), 797-804.

Asiedu-Appiah, F., \& Addai, H. (2014). An investigation into the causal relationship between employees' locus of control and contextual performance. Proceedings of ASBBS, 21(1), 41-59. 
Babalola, L. O. (2009). Personality trait and leadership effectiveness in work organizations. Journal of Psychology, 11(1), 37-46.

Boondhalir\&Sajeethkumar. (2020). Study on work locus of control and occupational stress among employees. Journal of Information and Computational Science, 10(8), 452-464.

Cetin, F. (2008). The effects of self concept, locus of control and personality on conflict resolution approaches in interpersonal relations: an applied research. Unpublished Master's Thesis, Military Academy, Military Academy of Defense Sciences Institute, Ankara.

Chuang, Y., \& Chien, H. (2013). A study of external locus of control on relationships among coping behavior on agency workers job satisfaction. The Journal of International Management Studies, $8(2), 54-65$.

Dayo, A. I. (2012). Locus of control and job satisfaction as predictors of Perceived non-teaching staffs ' productivity in higher institutions in Ogun State, Nigeria. Global Advanced Research Journal of Management and Business Studies, 1(6), 181-187.

Ennis, L. A. (2005). The evolution of technostress. Computers in Libraries, 25(8), 10-12.

Erdogan, B. (2003). Effects of background information and locus of control on student's control preferences in web-based instruction. Unpublished Master's Thesis, Ankara University, Education Sciences Institute, Ankara.

Gangai, M. K. N., Mahakud, G. C., \& Sharma, M. V. (2016). Association between locus of control and job satisfaction in employees: A critical review. The International Journal of Indian Psychology, 3(2), 16-25.

Hale, E. (2012). How your locus of control impacts business success. Fast Company, https://www.fastcompany.com/1840496/how-your-locus-control- impacts-business-success

Hauff, S., Richter, N. F., \& Tressin, T. (2015). Situational job characteristics and job satisfaction: The moderating role of national culture. International Business Review, 24(4), 710-723.

Houston, D. J. (2011). Implications of occupational locus and focus for public service motivation: Attitudes towards work motives across nations. Public Administration Review, 71(5), 761-771.

Hurrell, J. J., Levi, L.,\& Murphy, L. R. (2011). Locus of control. Encyclopedia of Occupational Health and Safety. Retrieved from www.ilo.org/oshenc/part- v/psychosocial-andorganizational-factors/individual-factors/item/54-locus-of- control.

Kalyanasundaram, P., Manickam, D., \& Senthilkumar, C. S. (2018). A study on relationship between locus of control and occupational stress at spinning mills with special reference to Coimbatore. International Journal of Pure and Applied Mathematics, 119(17), 2425-2435.

Khushk (2019). Impact of locus of control (loc) and organizational commitment on employee performance- study of service sector, Pakistan. International Journal of Law and Peace Works, 6(5), $1-6$.

Kobersy, I., Khasiyeva, L., Yakhina, V., Ignaryeva, O., Goloshchapova, L, Shkurkin, D., \& Sadykova, L. (2016). Approaches to implementation of motivation as the complex conditions of increase of efficiency of social and labour relations. International Review of Management and Marketing, 6(S1), 208-217.

Likert, R. (1932). A technique for the measurement of attitudes. Archives of Psychology, 22(140), 155.

Mahboob, A., \& Khan, T. (2016). Technostress and its management techniques: a literature review. Journal of Human Resource Management, 4(3), 28-31.

Maier, C. (2014). Technostress: theoretical foundation and empirical evidence. University of Bamberg.

Mandel, M. (2005). The real reasons you're working so hard. Business Week, Oct. 3, 60-67.

Manichander, T. (2014), Locus of control and performance: Widening applicabilities education. Paripex. Indian Journal of Research, 3(2), 1-9.

Mazmanian, M., Orlikowski, W.J. \& Yates, J. (2006). Crack berries: the social implications of ubiquitous wireless e-mail devices. In: C. Sørensen, Y. Yoo \& K. Lyytinen (Eds.). Designing Ubiquitous Information Environments: Socio-Technical Issues and Challenges. New York: Springer

Mohanta, G. C., Kannan, V., \& Thooyamani, K. P. (2006). Strategies for improving productivity of knowledge workers - an overview. strength-based strategies (pp. 77- 84). Hyderabad. 
Nasrullah, D., Armanu, M., \& Setiawan, S. (2013). Professionalism and locus of control influence on job satisfaction moderated by spirituality at work and its impact on performance auditor. International Journal of Business and Management Invention, 2(10), 1-11.

Nguyen, S. (2013). Locus of control: Stop making excuses and start taking responsibility. https://workplacepsychology.net/2013/06/05/locus-of- control-stop-making-excuses-and-starttaking-responsibility/

Olonade, Z. O., Ajibola, K. S., Oyewumi, O. O., Olusesi, L. D., \& Bamidele, D. E. (2020). Link between employees' locus of control, job satisfaction, and job stress among teachers: a survey analysis in Osun State of Nigeria. Quest Journal of Management and Social Sciences, 2(1), 1326.

Omukhango, M. A. (2016). Locus of control, employee age and job satisfaction at pacis insurance company limited Nairobi a research project submitted in partial fulfilment of the requirements for the award of the degree of master of business administration, school of business.

Qadri, Hassan \& Sheikh (2017). The mediating role of internal locus of control and job stress between spiritual intelligence and job performance. Pakistan Journal of Commerce and Social Sciences, 11(2), 623-643.

Robbins, P. S. (2003). Organization behaviour: concept, controversies, applications. seventh edition. prentice hall inc

Robbins, S. P., Judge, T. A. (2014). Perilaku organisasi (alih bahasa Drs. Benjamin Molan), Edisi Bahasa Indonesia, Klaten: PT. IntanSejati.

Sharma, R. R., \& Sharma, N. P. (2015). Opening the gender diversity black box: Causality of perceived gender equity and locus of control andmediation of work engagement in employee well-being. Frontiers in Psychology, 6, 1371-6.

Soleh, A., Noviantoro, R., \& Putrafinaldo, D. (2020). The effect of locus of control and communication toward employee performance. Management Sustainable Development Journal, 2(2), 41-52.

Soylu, A., \& Campbell, S. S. (2012). Physical and emotional stresses of technology on employees in the workplace. Journal of Employment Counselling, 49, 130-138.

Spector, P. (1988). Development of the work locus of control scale. Journal of Occupational Psychology, 61(4), 335- 340.

Srivatsava, A.K., \& Singh, A. P. (1981). Construction and standardization of an occupational stress index: A pilot study. Indian Journal of Clinical Psychology, 8(2), 133- 136

Stough S., Eom, S., \& Buckenmyer, J. (2000). Virtual teaming: a strategy for moving your organization into the new millennium. Industrial Management \& Data Systems, 100(8), 370378.

Suherlan, Q. A., Wahyuni, S., \& Hazairin, A. G. (2017). Relationship between locus of control and organizational commitment (Study on Employee of Multifinance Company PT. X Makassar Branch). Advances in Social Science, Education and Humanities Research, 127, 209-212

Sun, K., \& Chiou, H. (2011). Aviation ground crews: Occupational stresses and work performance. African Journal of Business Management, 5(7), 2865-2873.

Syahputra, Z. (2014). Influence of locus of control and organizational commitment on job satisfaction moderated by organizational culture and its impact on job performance. Journal of Economics and Sustainable Development, 5(17), 1044-110.

Taylor, H., Fieldman, G., \& Altman, Y. (2008). E-mail at work: a cause for concern? the implications of the new communication technologies for health, wellbleing and productivity at work. Journal of Organizational Transformation and Social Change, 5(2), 159-173.

Thomas W. H. N., Kelly, 1. S., \& Lillian T. E., (2006). Locus of control at work: a meta-analysis. Journal of Organizational Behaviour, 27, 107-118.

Tiemo, P. A., \& Ofua, J. O. (2010).Technostress: causes, symptoms and coping strategies among librarians in university libraries. Educational Research Journal, 1(12), 713-720.

Vijayashreea, L., \& Jagdischchandra, M. V. (2011). Locus of control and job satisfaction: psu employees. Serbian Journal of Management 6(2), 193-203.

Yuwono, H., Eliyana, A., Buchdadi, A. D., Hamidah, Sariwulan, T., \& Handicapilano, R. T. (2020). The effect of locus of control on employees' job satisfaction. Systematic Reviews in Pharmacy, $11(8), 43-50$. 